
Paleoclimatology

\author{
RESEARCH ARTICLE \\ 10.1029/2021PA004226 \\ Key Points: \\ - Deglacial authigenic manganese \\ peaks in the Southern Ocean and \\ abyssal Pacific are attributable to \\ changing bottom water oxygen \\ - Low- $\mathrm{O}_{2}$ bottom waters occupied the \\ entirety of the deep Pacific during \\ the Last Glacial Maximum \\ - Respired $\mathrm{CO}_{2}$ storage in the deep \\ Pacific is a characteristic feature of \\ late-Pleistocene glacial cycles since \\ Marine Isotope Stage 12
}

Supporting Information:

Supporting Information may be found in the online version of this article.

Correspondence to:

F. J. Pavia,

fjpavia@caltech.edu

Citation:

Pavia, F. J., Wang, S., Middleton, J., Murray, R. W., \& Anderson, R. F. (2021). Trace metal evidence for deglacial ventilation of the abyssal Pacific and Southern Oceans.

Paleoceanography and Paleoclimatology, 36, e2021PA004226. https://doi. org/10.1029/2021PA004226

Received 18 JAN 2021 Accepted 9 AUG 2021 (c) 2021. American Geophysical Union. All Rights Reserved.

\section{Trace Metal Evidence for Deglacial Ventilation of the Abyssal Pacific and Southern Oceans}

\author{
Frank J. Pavia ${ }^{1,2,3}$ (D), Shouyi Wang ${ }^{4}(\mathbb{D})$, Jennifer Middleton ${ }^{1}$ (D), Richard W. Murray ${ }^{4}$, and \\ Robert F. Anderson ${ }^{1,2}$ (D) \\ ${ }^{1}$ Lamont-Doherty Earth Observatory of Columbia University, Palisades, NY, USA, ${ }^{2}$ Department of Earth and \\ Environmental Sciences, Columbia University, New York, NY, USA, ${ }^{3}$ Now at Division of Geological and Planetary \\ Sciences, California Institute of Technology, Pasadena, CA, USA, ${ }^{4}$ Woods Hole Oceanographic Institution, Woods Hole, \\ MA, USA
}

\begin{abstract}
The deep ocean has long been recognized as the reservoir that stores the carbon dioxide $\left(\mathrm{CO}_{2}\right)$ removed from the atmosphere during Pleistocene glacial periods. The removal of glacial atmospheric $\mathrm{CO}_{2}$ into the ocean is likely modulated by an increase in the degree of utilization of macronutrients at the sea surface and enhanced storage of respired $\mathrm{CO}_{2}$ in the deep ocean, known as enhanced efficiency of the biological pump. Enhanced biological pump efficiency during glacial periods is most easily documented in the deep ocean using proxies for oxygen concentrations, which are directly linked to respiratory $\mathrm{CO}_{2}$ levels. We document the enhanced storage of respired $\mathrm{CO}_{2}$ during the Last Glacial Maximum (LGM) in the Pacific Southern Ocean and deepest Equatorial Pacific using records of deglacial authigenic manganese, which form as relict peaks during increases in bottom water oxygen (BWO) concentration. These peaks are found at depths and regions where other oxygenation histories have been ambiguous, due to diagenetic alteration of authigenic uranium, another proxy for BWO. Our results require that the entirety of the abyssal Pacific below approximately 1,000 $\mathrm{m}$ was enriched in respired $\mathrm{CO}_{2}$ and depleted in oxygen during the LGM. The presence of authigenic $\mathrm{Mn}$ enrichment in the deep Equatorial Pacific for each of the last five deglaciations suggests that the storage of respired $\mathrm{CO}_{2}$ in the deep ocean is a ubiquitous feature of late-Pleistocene ice ages.
\end{abstract}

\section{Introduction}

Ice core records show coherent variability between temperature and atmospheric $p \mathrm{CO}_{2}$ across the last eight Pleistocene glacial cycles (Petit et al., 1999). Identifying the processes that drove these concomitant changes lies at the heart of Quaternary paleoclimatology. It has been established for nearly 40 years that the majority of the $\sim 100 \mathrm{ppm}$ lower atmospheric $p \mathrm{CO}_{2}$ during late Pleistocene glacial periods must be stored in the deep ocean, based on its size and rapidity of exchange with the atmosphere (Broecker, 1982). The mechanisms for greater oceanic $\mathrm{CO}_{2}$ storage have been long-debated, but an abundance of evidence now points toward changes in the global efficiency of the biological pump (Knox \& McElroy, 1984; Sigman et al., 2010; Volk \& Hoffert, 1985) as one of the main drivers.

The most powerful evidence for global changes in the efficiency of the biological pump comes from fossil-bound nitrogen isotopes, which show an enhanced degree of surface nutrient utilization during the last glacial period in the North Pacific (e.g., Ren et al., 2015) as well as in the Southern Ocean (Ai et al., 2020; Martínez-Garcia et al., 2014; Sigman et al., 1999; Studer et al., 2015; Wang et al., 2017). However, the deep sea manifestation of this signal, the occurrence of greater respired carbon storage in the ocean interior, has proved elusive. Since the respiration of organic matter is stoichiometrically linked to the consumption of $\mathrm{O}_{2}$, reconstructing changes in bottom water oxygen (BWO) has long been suggested as a path forward for determining the role of the biological pump in driving glacial-interglacial $\mathrm{CO}_{2}$ variability (Boyle, 1990; Sigman et al., 2010).

In the last several years, significant progress has been made on both qualitative and semi-quantitative methods for reconstructing BWO. The differences in carbon isotope ratios between infaunal and epifaunal benthic foraminifera species (Gottschalk et al., 2016; Hoogakker et al., 2015, 2018; Umling \& Thunell, 2018), as well as the ratio of iodine to calcium in foraminifera shells ( $\mathrm{Lu}$ et al., 2020) are avenues for recording dissolved oxygen changes in bottom waters, though these proxies are complicated to interpret quantitatively 
(Jacobel et al., 2020). In addition to the geochemistry of benthic fauna, deep sea sediments themselves can record these oxygen changes through time. Such sediment redox proxies include the variability of hydrothermally derived trace element concentrations (Mills et al., 2010), the presence and absence of redox-sensitive magnetite (Korff et al., 2016), the abundance of authigenic trace metals paired with biogenic flux proxies (Bradtmiller et al., 2010; Jaccard et al., 2009), and the preservation of algal biomarkers (Anderson et al., 2019).

While there is growing evidence for the glacial storage of respired $\mathrm{CO}_{2}$ in the deep ocean, the release of respired $\mathrm{CO}_{2}$ from the deep ocean during deglaciations has been difficult to prove. Reconstructions of carbon release based on benthic $\delta^{13} \mathrm{C}$ and $\mathrm{B} / \mathrm{Ca}$ exist from the South Pacific at depths from 1 to $2.5 \mathrm{~km}$ and suggest rapid deglacial ocean degassing of respired $\mathrm{CO}_{2}$ (Allen et al., 2015, 2020), but do not yet extend deeper $(>2,500 \mathrm{~m})$ into the most voluminous waters of the Pacific basin. Additionally, reconstructions of glacial-interglacial oceanic-atmosphere carbon exchange typically do not extend back to the earliest glacial cycles of the last $1 \mathrm{Ma}$.

Here, we present new evidence for deglacial ventilation of the deep Pacific and Southern oceans using records of authigenic Mn. The redox-solubility behavior of Mn makes it an ideal tracer for the transition from low-BWO to high-BWO conditions, since it is soluble under suboxic conditions and insoluble under oxic conditions. We find authigenic Mn peaks during the last deglaciation in cores from the Pacific Southern Ocean, and from the last five deglaciations in cores from the Equatorial Pacific. Since these records come from locations with either negligible glacial-interglacial changes in export productivity (Equatorial Pacific) or increasing deglacial export production (Polar Southern Ocean), the authigenic Mn peaks must reflect greater ventilation of the abyssal Pacific during the last deglaciation and the release of respired $\mathrm{CO}_{2}$ to the atmosphere.

\section{Sedimentary Mn Geochemistry}

The utility of Mn as a tracer of BWO changes relies on its redox-solubility behavior. Mn is soluble in its reduced form as $\mathrm{Mn}$ (II), and more insoluble in its oxidized forms $\mathrm{Mn}$ (III) and $\mathrm{Mn}(\mathrm{IV})$, which readily precipitate as oxides under oxygenated conditions (Calvert \& Pedersen, 1996). As a result, the residence time of dissolved manganese in oxygenated deep ocean waters is short, with estimates varying from 10 to 40 years (Bruland et al., 1994; Hayes et al., 2018). In sedimentary systems, the behavior of Mn depends on porewater redox conditions. Sediments buried under oxic porewater conditions would be expected to have authigenic solid-phase $\mathrm{Mn}$ present as $\mathrm{MnO}_{2}$ coatings, and sediments buried in reducing settings should have no authigenic solid Mn, with Mn instead found as dissolved Mn(II) in porewaters.

Early porewater diagenetic profiles showed that the reduction of solid-phase $\mathrm{MnO}_{2}$ and release of aqueous $\mathrm{Mn}(\mathrm{II})$ begins at or near the depth horizon of complete porewater $\mathrm{O}_{2}$ consumption (Froelich et al., 1979). This behavior allows for the development of solid $\mathrm{MnO}_{2}$ "spikes" just above the depth of complete $\mathrm{O}_{2}$ consumption, generated as follows. When sediments containing $\mathrm{MnO}_{2}$ are buried beneath this depth, authigenic solid $\mathrm{Mn}$ is reduced and solubilized. This dissolved $\mathrm{Mn}$ (II) then diffuses upwards toward the depth just above complete $\mathrm{O}_{2}$ consumption, where the dissolved $\mathrm{Mn}(\mathrm{II})$ is oxidized and reprecipitated as solid $\mathrm{Mn}$ (Figure 1). As a result, at steady state, a spike in solid-phase $\mathrm{MnO}_{2}$ develops at the horizon just above where porewater oxygen vanishes (Burdige \& Gieskes, 1983; Froelich et al., 1979). The depth of this porewater redox front is controlled by BWO concentration, organic carbon flux to the sediments, and sedimentation rate (e.g., Mangini et al., 2001).

Downcore peaks in authigenic Mn concentration have been observed previously, but interpretations of Mn spikes in deglacial sediments have varied widely. Arguments that glacial deep ocean suboxia drove the release of $\mathrm{Mn}$ (II) to seawater, followed by scavenging and reburial upon deglacial ventilation (Mangini et al., 1990, 1991, 1994), have largely been ruled out on the basis that the glacial deep ocean was not suboxic (Anderson et al., 2019; Hoogakker et al., 2018; Yang et al., 1995). Thus, deglacial Mn peaks must reflect the preservation of shallow steady-state manganese peaks formed under glacial conditions. As pore water oxygen increased during the deglaciation, the shallow steady-state manganese peak formed under glacial conditions is preserved due to the deepening of the porewater redox horizon where $\mathrm{O}_{2}$ is completely consumed (Figure 1). 


\section{1) Glacial Conditions}

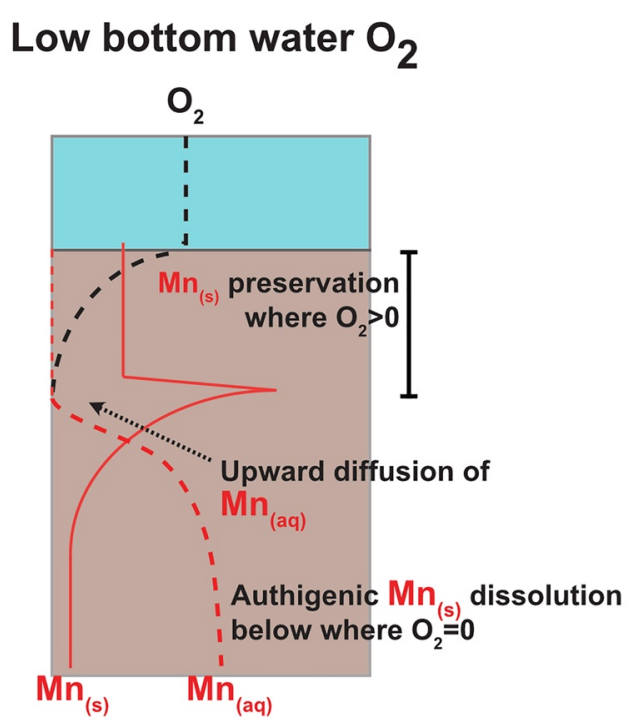

2) Deglacial Conditions
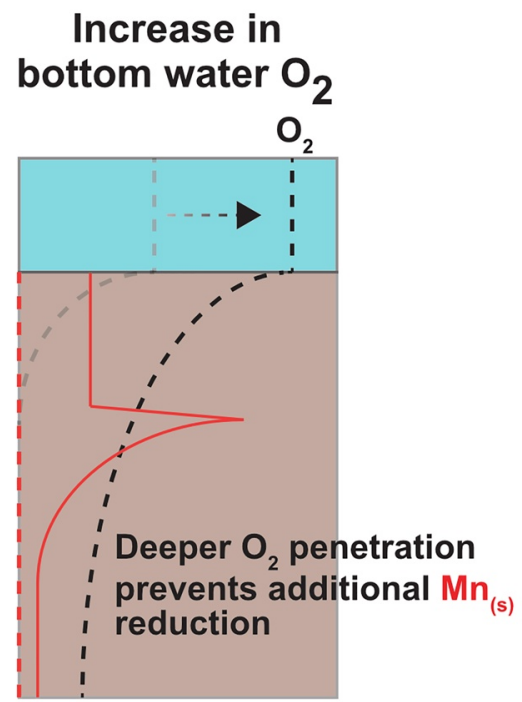

3) Holocene Conditions
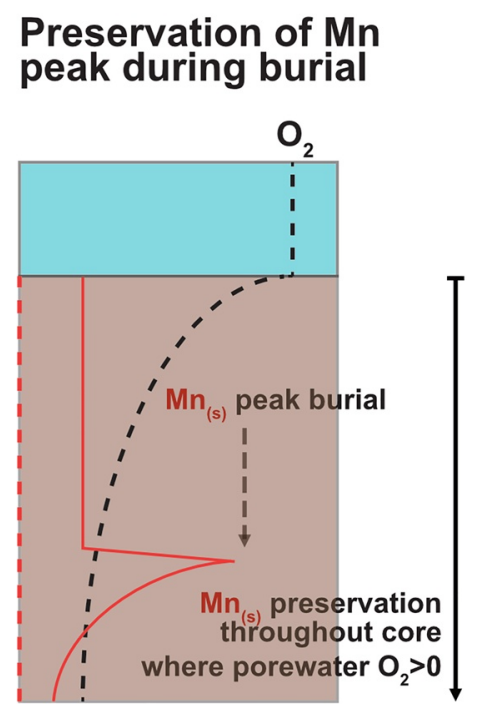

Figure 1. Cartoon schematic illustrating the principles of steady state $\mathrm{MnO}_{2}$ peak formation in sediments buried under low-bottom water oxygen (BWO) conditions (left), the shift in porewater oxygen profiles induced by increased BWO allowing for the preservation of the relict steady-state peak (center), and the preservation of the relict Mn peak during subsequent sediment burial under oxic porewater conditions. Black and gray dashed lines show dissolved oxygen profiles in porewaters, red dashed lines show porewater dissolved manganese $\left(\mathrm{Mn}_{(\mathrm{aq})}\right)$ profiles, and the solid red lines show the solid phase manganese $(\mathrm{Mn}(\mathrm{s}))$ profiles. Aqueous manganese is produced under reducing conditions, while solid-phase manganese is produced under oxic conditions.

The complete sequence of events leading to preserved diagenetic Mn peaks driven by low-BWO is summarized in Figure 1. During glacial periods, a shallower porewater redox gradient compared to interglacials allowed for the development of a steady-state solid-phase Mn peak (Figure 1, left panel). During the deglaciation, a deepening of the pore water redox gradient inhibits the reduction of additional solid Mn at depths below the previous steady-state Mn peak (Figure 1, center panel). Then, as sediment accumulation continues with the same, deeper porewater redox gradient, the glacial solid-phase Mn peak continues to be preserved as it is buried throughout intervals where pore water oxygen is not fully consumed. Thus, the signal we infer from measuring a deglacial solid-phase Mn peak in a sediment core is the deepening of the porewater redox front, allowing for the preservation of a relict steady-state solid-phase manganese peak.

The deglacial deepening of the porewater depth at which oxygen is fully consumed can be achieved either through a decrease in the supply of organic matter to sediments, or an increase in BWO concentrations. Decreasing the supply of organic matter to sediments reduces the rate at which oxygen is consumed by aerobic respiration in porewaters, thus allowing porewater oxygen concentrations to persist to greater depths. Increasing BWO concentrations push the initial $\mathrm{O}_{2}$ content of the porewaters higher, allowing porewater oxygen concentrations to reach greater depths for a given organic matter supply.

Deglacial Mn spikes can thus only be uniquely attributed to increased BWO concentrations in locations where export productivity (i.e., sedimentary organic matter supply) is either constant, or increasing through the deglaciation. Early studies attributed deglacial Mn peaks in the Equatorial Pacific to high export productivity during glacial periods that rapidly declined during deglaciation (Berger et al., 1983; Finney et al., 1988). However, recent syntheses of flux-normalized export productivity proxies have shown that export productivity was either unchanged or lower during the Last Glacial Maximum (LGM) throughout the Equatorial Pacific (Costa et al., 2017). Thus, it is likely that these relict deglacial Mn peaks in the Equatorial Pacific are due to changing BWO conditions, rather than changing productivity.

We thus focus this study on sites where export production was lower during the LGM than the Holocene (Figure 2), in the Equatorial Pacific (Costa et al., 2017) and South of the Antarctic Polar Front in the Southern Ocean (Kohfeld et al., 2005). In this paper, we present new Mn records for select sediment cores with existing productivity proxy data that allow us to rule out decreasing deglacial export production as a driver 


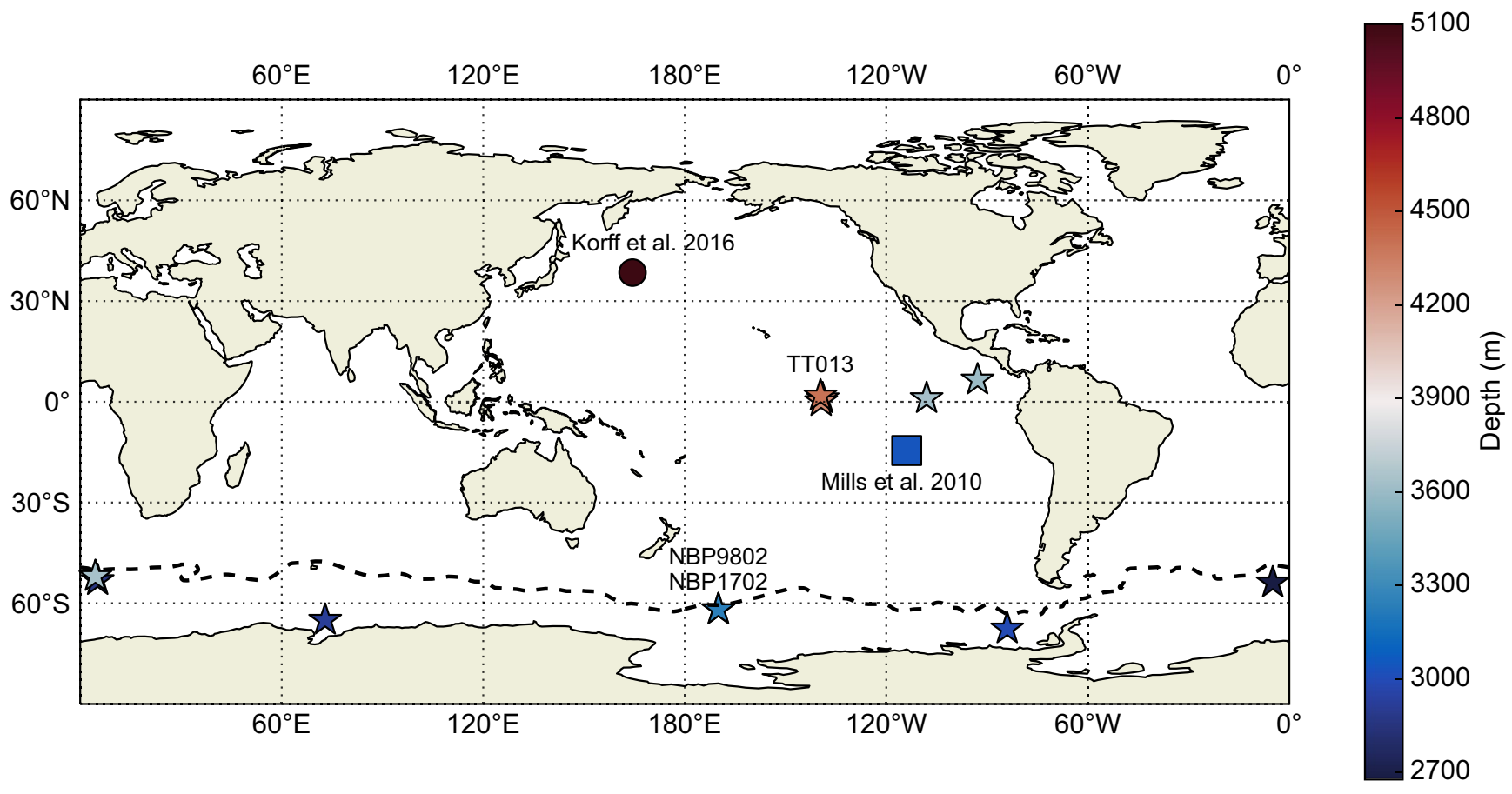

Figure 2. Map showing locations and depths of cores discussed in this study. Cores with deglacial Mn peaks that can be attributed to increasing bottom water oxygen concentrations are shown as stars. Dashed black line shows the location of the Antarctic Polar Front. Table 2 contains the names, locations, depths, and references for all cores on this map.

of our Mn peaks. When discussing historical measurements of deglacial Mn spikes, we either note the co-located evidence against decreasing deglacial export production or the regional coherence of export production reconstructions from the locations of these sites. In order to avoid effects of variable dilution by other sedimentary constituents, we identify Mn spikes both on the basis of Mn concentrations and peaks in Mn relative to other lithogenic constituents, such as Fe or Ti.

\section{Materials and Methods}

\subsection{Sample Locations}

We present new data from four sediment cores (Figure 2). Piston cores NBP9802-6PC $\left(-61.88^{\circ} \mathrm{N}, 169.98^{\circ} \mathrm{W}\right.$, $3,245 \mathrm{~m}$ water depth) and NBP1702-7JPC $\left(-61.88^{\circ} \mathrm{N}, 169.98^{\circ} \mathrm{W}, 3,264 \mathrm{~m}\right.$ water depth) were collected from the Pacific sector of the Antarctic Southern Ocean. In the modern ocean, these core locations are bathed by

Table 1

Age Model Tie-Points From Planktonic ${ }^{14}$ C Measurements Made on N. pachyderma From NBP1702-07JPC

\begin{tabular}{lcccccc}
\hline $\begin{array}{l}\text { Accession } \\
\text { number }\end{array}$ & $\begin{array}{c}\text { Top depth } \\
(\mathrm{cm})\end{array}$ & $\begin{array}{c}\text { Bottom depth } \\
(\mathrm{cm})\end{array}$ & 14C age & $\begin{array}{c}\text { 1-sigma 14C } \\
\text { age error }\end{array}$ & $\begin{array}{c}\text { Reservoir age (yrs) } \\
\text { (Butzin et al., 2020) }\end{array}$ & $\begin{array}{c}\text { Calendar } \\
\text { age (yrs BP) }\end{array}$ \\
\hline OS-143452 & 10 & 11 & 3,040 & 15 & 1,280 & 19,10 \\
OS-143451 & 50 & 51 & 10,500 & 35 & 1,280 & 10,878 \\
OS-147240 & 82 & 83 & 18,600 & 100 & 2,138 & 20,252 \\
OS-147241 & 85 & 86 & 19,900 & 120 & 2,138 & 21,767 \\
OS-143449 & 88 & 89 & 21,100 & 120 & 2,138 & 23,065 \\
OS-147188 & 91 & 92 & 23,100 & 270 & 2,138 & 25,204 \\
\hline
\end{tabular}

Note. Surface reservoir ages were taken from the time-dependent model of Butzin et al. (2020), using the values from the nearest grid box to the NBP1702-07JPC core. 
Table 2

List of Cores Discussed in This Study and Shown Visually in Figure 2

\begin{tabular}{lccccc}
\hline Core & Lat. $\left({ }^{\circ} \mathrm{N}\right)$ & Lon. $\left({ }^{\circ} \mathrm{E}\right)$ & Depth $(\mathrm{m})$ & References & Proxy \\
\hline MANOP C & 0.953 & 221.045 & 4,287 & Prahl et al., 1989 & Mn \\
MANOP H & 6.55 & 267.183 & 3,600 & Finney et al., 1988 & Mn \\
TT013-PC72 & 0.1 & 220.6 & 4,300 & This study & Mn \\
TT013-PC18 & 1.8 & 220.4 & 4,400 & This study & Mn \\
PLDS72 & 1 & 252 & 3,626 & Berger et al., 1983 & Mn \\
ANT30/P1-02 & -65.01 & 72.94 & 2,916 & Wu et al., 2018 & Mn \\
TN057-13PC & -53.2 & 5.2 & 2,848 & Jaccard et al., 2016 & Mn \\
RC13-259 & -53.88 & 355.067 & 2,677 & Kumar, 1994 & Mn \\
RC13-271 & -51.99 & 4.522 & 3,634 & Kumar, 1994 & Mn \\
Many cores & -64 to -70 & $265-291$ & $2,300-3,900$ & Hillenbrand et al., 2021 & Mn \\
NBP1702-07JPC & -61.875 & 190 & 3,264 & Thisstudy & Mn \\
NBP9802-06PC & -61.874 & 190 & 3,245 & This study & Mn \\
GS7202-35 & -14.798 & 246.5 & 3,044 & Mills et al., 2010 & U/Fe \\
SO202-39-3 & 38.011 & 164.446 & 5,102 & Korff et al., 2016 & Magnetite Dissolution \\
\hline
\end{tabular}

Note. The cores with proxy listed as Mn have deglacial authigenic Mn peaks, and either have downcore proxy evidence for increasing or constant export productivity from last glacial maximum to Holocene, or are from regions (Equatorial Pacific or Southern Ocean south of the Antarctic Polar Front) that are established to have had that deglacial export productivity pattern.

Antarctic Bottom Water (AABW) at the seafloor with dissolved $\mathrm{O}_{2}$ concentrations of $215 \mu \mathrm{mol} / \mathrm{kg}$. We also discuss results from two piston cores collected from the Central Equatorial Pacific during the JGOFS program. TT013-PC72 $\left(0.1137^{\circ} \mathrm{N}, 139.4015^{\circ} \mathrm{W}, 4,398 \mathrm{~m}\right.$ water depth) and TT013-PC18 $\left(-1.8395^{\circ} \mathrm{N}, 139.7157^{\circ} \mathrm{W}\right.$, 4,354 m water depth) are bathed by a mixture of AABW and Circumpolar Deepwater with abyssal oxygen concentrations of $168 \mu \mathrm{mol} / \mathrm{kg}$ (http://usjgofs.whoi.edu/jg/dir/jgofs/eqpac/).

\subsection{Trace Metal Analyses}

X-ray Fluorescence (XRF) analysis of NBP9802 and NBP1702 cores was performed on an ITRAX Core Scanner Machine at Lamont Doherty Earth Observatory's Core Repository Laboratory. Configurations for the scans were: $2 \mathrm{~mm}$ steps for 6JPC and $5 \mathrm{~mm}$ steps for 7JPC with a Molybdenum Tube, at $30 \mathrm{kV}$ voltage, $30 \mathrm{~mA}$ current, and $15 \mathrm{~s}$ per scan. TT013-PC72 and TT013-PC18 Fe, Mn, Ti, and Al elemental data were measured on an ICP-OES machine at Boston University using a Jobin Yvon JY24 sequential spectrometer. Precision was determined by replicate analysis of natural JGOFS sediments included in each analytical batch and was determined to be better than $3 \%-4 \%$ for these elements. Accuracy of elemental analysis was determined based on multiple analyses of the NIST reference material SRM-1C, an argillaceous limestone. Additional details on the methods for metal analysis on TT013 cores can be found in the publications originally presenting the data (Murray et al., 1995, 2000).

\subsection{Age Model Construction}

Age models for Equatorial Pacific cores TT013-PC72 and TT013-PC18 have been described previously (Murray et al., 2000). We constructed the age model for NBP1702-7JPC using six radiocarbon dates made on monospecific samples of the planktonic foraminifer N. pachyderma. Radiocarbon analyses were performed at the National Ocean Sciences Accelerator Mass Spectrometry (NOSAMS) facility at Woods Hole Oceanographic Institution. Reservoir corrections for radiocarbon ages are poorly understood in the Southern Ocean. Previous studies have documented time-varying planktonic reservoir ages reaching several thousands of years in the South Pacific, both off the New Zealand Margin and in the open Southern Ocean, 
just north of the Subantarctic Front (Ronge et al., 2016). No data exist for reservoir corrections south of the Antarctic Polar Front in the Pacific Southern Ocean. We adopt the reservoir age estimates from the model of Butzin et al. (2020). For the 10 and $50 \mathrm{~cm}{ }^{14} \mathrm{C}$ dates, we use the time mean reservoir age between 12 and $10 \mathrm{kyr}$ BP from the Butzin et al. model ( $\Delta \mathrm{R}=1,280$ years). For the $82,85,88$, and $91 \mathrm{~cm}{ }^{14} \mathrm{C}$ dates, we use the time mean reservoir age averaged between 23 and $19 \mathrm{kyr} B P$ of $\Delta \mathrm{R}=2,138$ years. Radiocarbon dates were converted to calendar years using the OxCal program version 4.3, the SHCal20 calibration curve, and the reservoir ages listed above (Table 1). The age model for this core was constructed via linear interpolation between radiocarbon dates (Figure S1 and Table S1).

After constructing the NBP1702 age model, we updated the age model of NBP9802-6PC from that published in Chase et al. (2003) by aligning the XRF Fe counts to those of NBP1702-7JPC (Figure S1). The previous age model for NBP9802 had been based on ${ }^{14} \mathrm{C}$ dates on bulk $\mathrm{CaCO}_{3}$ (Chase et al., 2003). However, in two other cores collected on the NBP9802 expedition, radiocarbon dates of glacial-age mixed planktonic foraminifera were 3,000 years younger than bulk $\mathrm{CaCO}_{3}$ ages, likely due to inputs of ${ }^{14} \mathrm{C}$-dead detrital $\mathrm{CaCO}_{3}(\mathrm{Chase}$ et al., 2003). Thus, we argue that correlating the XRF Fe record of NBP9802-6PC to that of foraminiferal ${ }^{14} \mathrm{C}$-dated NBP1702-7JPC is a better method for determining ages. The alignment of XRF Fe counts in NBP9802-6PC and NBP1702-7JPC is shown in Figure 3. The age-depth model of NBP9802-6PC was generated by linearly interpolating between tie points.

\section{Results}

Evidence of deglacial ventilation of Pacific bottom waters comes from profiles of authigenic Mn of Southern Ocean cores NBP1702-07PC and NBP9802-06PC as well as Equatorial Pacific cores TT0-13-PC72 and TT013-PC18. We isolate the authigenic component of Mn by normalizing to lithogenic elements Fe and Ti. $\mathrm{Mn} / \mathrm{Fe}$ and $\mathrm{Mn} / \mathrm{Ti}$ ratios therefore provide insights into redox sensitive processes in the sediment profile.

Pacific Southern Ocean cores NBP9802 and NBP1702 have low Mn/Fe ratios during the last glacial period that increase rapidly during the deglaciation, and maintain a high steady baseline value throughout the Holocene (Figure 4). The timing of the deglacial Mn/Fe peak is marginally offset between the two cores, either due to differences in glacial porewater redox conditions driven by variable accumulation rates between the two cores, or due to slight misalignment in wiggle matching the two age models. The low Mn/Fe ratios during the last glacial period and subsequent peak during Termination 1

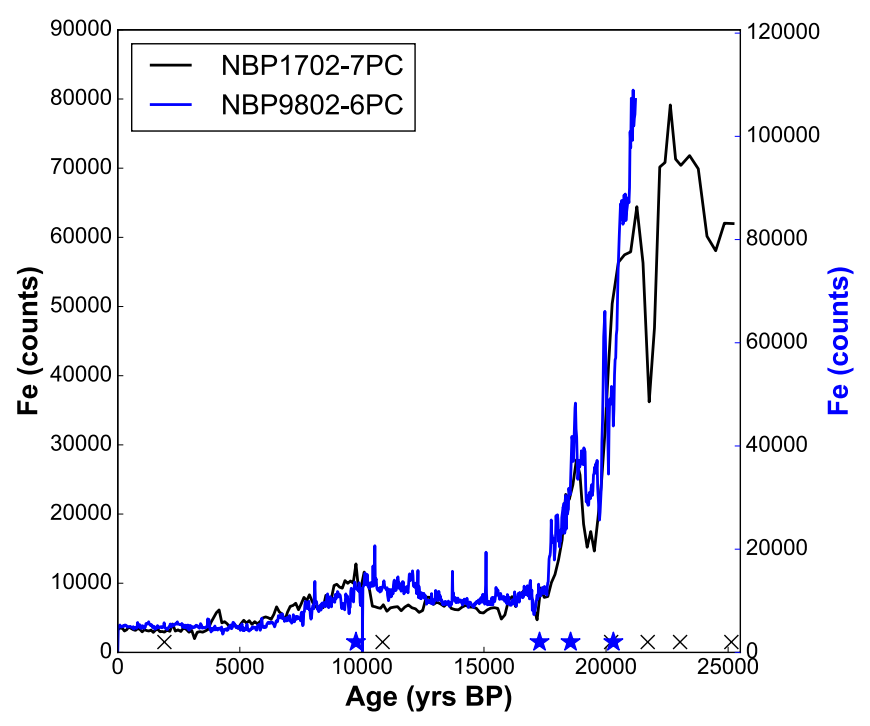

Figure 3. XRF Fe counts on aligned age model for NBP1702-7JPC (black) and NBP9802-6PC (blue). Markers at top show the ages of tie points for each core: Black X marks denote reservoir-corrected planktonic $14 \mathrm{C}$ dates on NBP1702-7JPC, and blue stars show tie points between the XRF Fe counts of NBP1702-7JPC and NBP9802-6PC. match theoretical predictions of upward diffusion of soluble authigenic $\mathrm{Mn}$ in response to oxygen depletion at depth (Froelich et al., 1979). In the late deglacial and Holocene section of the cores, authigenic Mn persists, with $\mathrm{Mn} / \mathrm{Fe}$ ratios (counts per counts) between 0.1 to 0.2 that are higher than ratios during the preceding glacial period. The raw counts of $\mathrm{Mn}$ show a peak during the deglaciation as well (Figure S2), indicating that these $\mathrm{Mn} / \mathrm{Fe}$ peaks are not driven by changes in $\mathrm{Fe}$, but by the formation of authigenic Mn. These results are consistent with our conceptual model where glacial-age Mn was dissolved below a shallow horizon of complete porewater oxygen consumption, diffused upwards toward a steady-state solid-phase Mn peak, and subsequently preserved following a deglacial deepening of the porewater oxygen consumption depth.

Equatorial Pacific cores TT013-PC72 and TT013-PC18 show similar authigenic Mn profiles based on $\mathrm{Mn} / \mathrm{Fe}$ mass ratios. Glacial $\mathrm{Mn} / \mathrm{Fe}$ ratios vary between 0.2 and $0.3 \mathrm{~g} / \mathrm{g}$ with a rapid increase during deglaciations over the last $500 \mathrm{kyr}$ (Figures 5-7). In PC18, Mn/Fe ratios abruptly rose to 1.5 at $15 \mathrm{ka}$, and in PC72, a spike of $2.0 \mathrm{Mn} / \mathrm{Fe}$ is found at $11 \mathrm{ka}$. Following the rapid peaks, authigenic Mn steadily declines into the Holocene akin to Southern Ocean profiles. In TT013-PC72 and TT013-PC18, deglacial authigenic Mn peaks extend beyond the last glacial termination. $\mathrm{Mn} / \mathrm{Fe}$ ratios of both cores periodically spike during deglaciations all the way back to $500 \mathrm{ka}$ (Figures 5 and 7). The magnitudes of the deglacial 


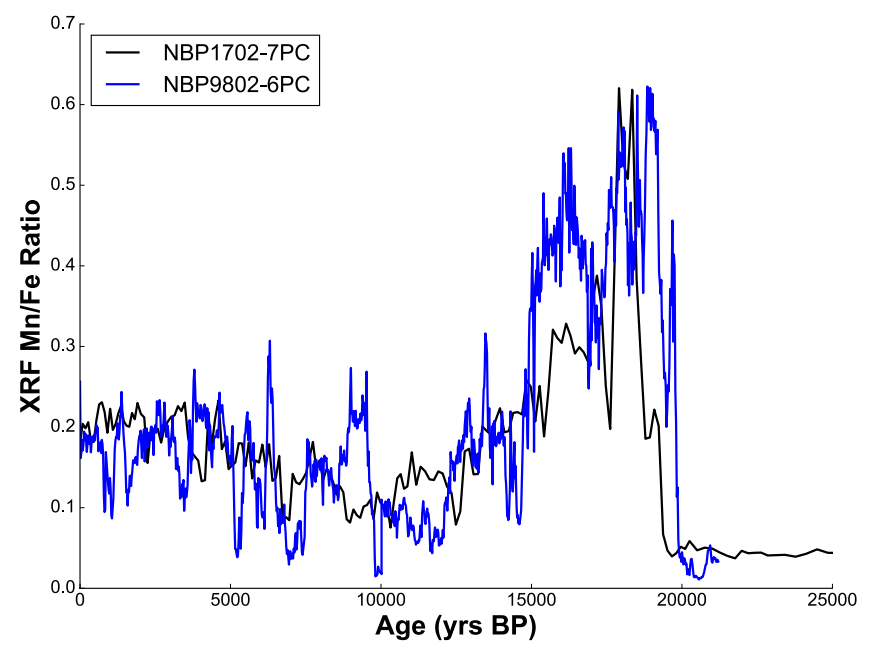

Figure 4. Uncalibrated scanning XRF $\mathrm{Mn} / \mathrm{Fe}$ ratios measured in NBP9802-6PC (blue) and NBP1702-7JPC (black).
$\mathrm{Mn} / \mathrm{Fe}$ spikes typically differ between cores and are generally larger in PC72 than in PC18. Before $500 \mathrm{ka}$, there are no distinct deglacial spikes in $\mathrm{Mn} / \mathrm{Fe}$ ratios at these cores-though the ratios seem to broadly increase in both cores around $750 \mathrm{ka}$ followed by a long-term decrease until $500 \mathrm{ka}$ (Figure 7). The PC72 Mn/Fe record also shows variability from 900 to $1,100 \mathrm{ka}$, but again without the distinct, rapid spikes apparent from 0 to $500 \mathrm{ka}$ (Figures 5 and 7).

\section{Discussion}

\subsection{Drivers of Preserved Deglacial Mn Peaks}

Deglacial Mn peaks can only be interpreted in terms of changing BWO concentrations when decreasing deglacial export productivity can be ruled out. At NBP9802, opal flux and ${ }^{231} \mathrm{~Pa} /{ }^{230} \mathrm{Th}$ increase through the deglaciation (Anderson et al., 2009; Chase et al., 2003). This is consistent with the pattern of lower export production south of the Antarctic Polar Front (APF) during the LGM compared to the Holocene (Kohfeld et al., 2005). While we have not generated export production records from NBP1702, this site is a reoccupation of the NBP9802 location. Thus, we can safely attribute the deglacial Mn peaks at both of these sites as being due to increased BWO during the deglaciation.

Mn peaks in the Central Equatorial Pacific TT013 cores can similarly be ascribed to increasing deglacial BWO. Winckler et al. (2016) measured ${ }^{230}$ Th-normalized excess barium $\left(\mathrm{Ba}_{\mathrm{xS}}\right)$ and opal fluxes over the last $500 \mathrm{kyr}$ in TT013-PC72, showing that export productivity peaks during terminations I, II, and IV, with no notable change across termination III. While there is not a record of similar length at TT013-PC18, Anderson et al. (2019) found that the deglacial patterns of opal and $\mathrm{Ba}_{\mathrm{xs}}$ fluxes at PC18 closely co-varied with those at PC72. This close coupling between fluxes at the two sites also holds true for $\mathrm{CaCO}_{3}$ (Anderson et al., 2008) and dust (Anderson et al., 2006) over the past 200 kyr. Thus, we argue that the pattern of unchanging or increasing deglacial export productivity found at PC72 over the past $500 \mathrm{ka}$ is applicable to the conditions at PC18 as well, and that each of the deglacial Mn peaks found at these core sites are driven by increasing BWO.

\subsection{Depth Distribution of Respired $\mathrm{CO}_{2}$ in the Pacific Ocean During the LGM}

Evidence for low BWO and high respired $\mathrm{CO}_{2}$ contents of the abyssal Pacific during Pleistocene glacial periods has come in large part from measurements of authigenic uranium concentrations (aU). In our cores both from the Equatorial Pacific (Anderson et al., 2006; Jacobel et al., 2020) and Pacific Southern Ocean (Chase et al., 2003), ventilation-driven deglacial authigenic Mn peaks are not complemented by preceding glacial maxima in aU. Uranium has opposing solubility-redox behavior in porewaters compared to manganese, as it is found in the soluble U(VI) state under oxic conditions and precipitates as insoluble U(IV) under low-oxygen conditions (Anderson, 1982; Barnes \& Cochran, 1990). The reduction and precipitation of U occurs near the redox potential of Fe reduction (McManus et al., 2005). As $U$ is precipitated and removed from solution in porewaters, a downward concentration gradient drives a diffusive flux of $U$ from seawater into sediments, generating sedimentary peaks of authigenic $U$ during intervals of low-BWO or high organic carbon flux (McManus et al., 2005). Throughout the Atlantic, complementary aU peaks are found during glacial periods in the same cores as deglacial Mn peaks, as might be expected from the opposing redox behavior of these two elements and the corroborating change from low-BWO to higher-BWO between glacial periods and deglaciations (Mangini et al., 2001).

A recent synthesis of LGM aU measurements from the Equatorial Pacific showed that cores above 3,500 $\mathrm{m}$ consistently show LGM aU peaks that reflect low BWO, but cores below 3,500 m typically do not have glacial aU peaks (Jacobel et al., 2020). However, the absence of aU peaks in marine sediments does not necessarily imply that aU peaks never formed, or that sedimentary redox conditions did not change. During the transition from low- $\mathrm{O}_{2}$ to higher- $\mathrm{O}_{2}$ sedimentary redox state (e.g., that driven by a deglacial increase in BWO), 

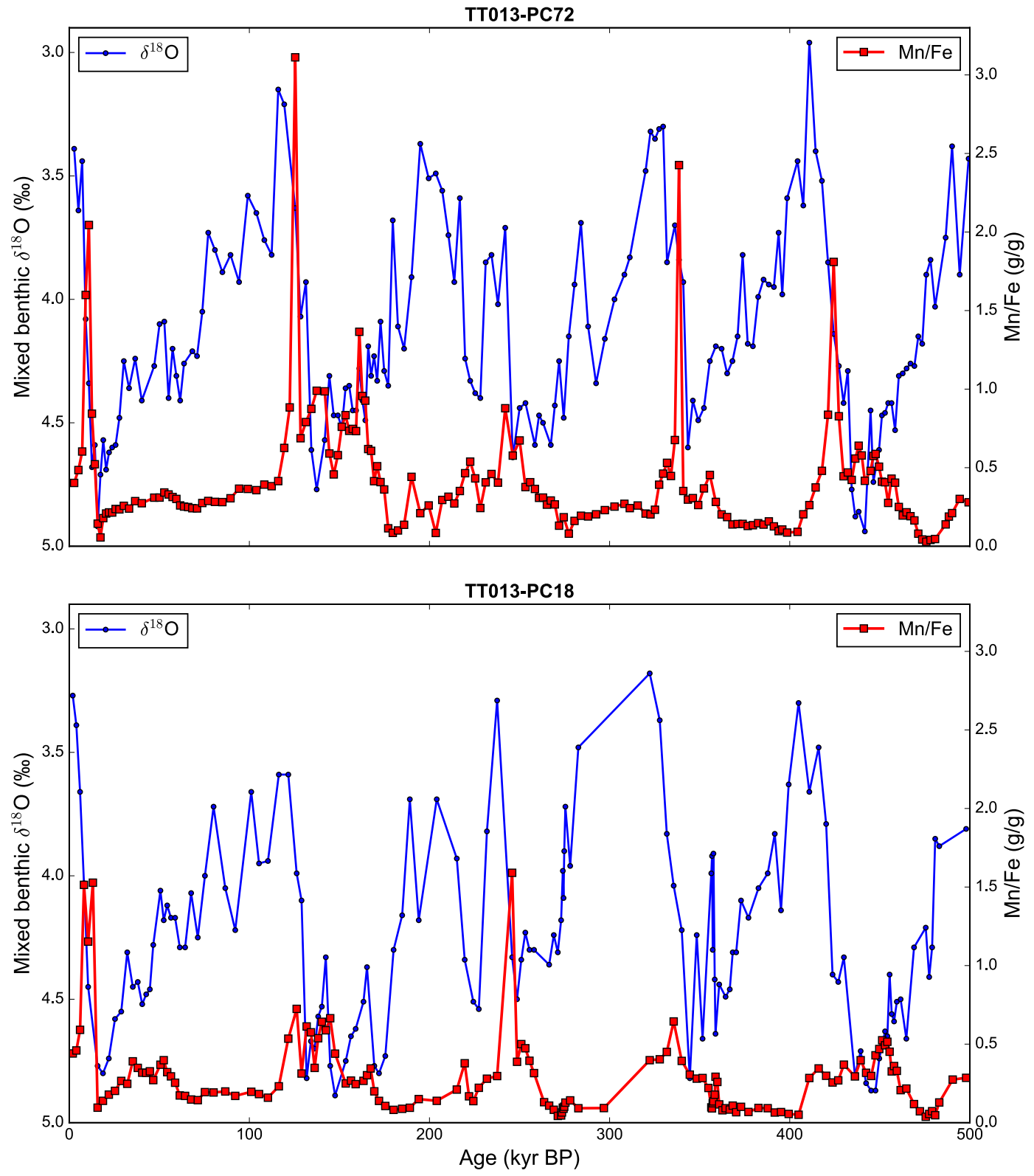

Figure 5. $\mathrm{Mn} / \mathrm{Fe}$ ratios (g/g, shown in red) and mixed benthic $\delta^{18} \mathrm{O}$ (per mille, shown in blue) from Equatorial Pacific cores TT013-PC72 (top panel) and TT013-PC18 (bottom panel). Oxygen isotope data are from Murray et al. (2000).

solid-phase aU can be oxidized, remobilized to aqueous $\mathrm{U}(\mathrm{VI})$, and diffuse out of the sediment column, a process deemed "burndown" (Colley et al., 1989; Jacobel et al., 2017; Shaw et al., 1994). Thus, cores without glacial aU deposits could either have never formed aU in the first place, or have formed aU that was subsequently remobilized out of the sediments during the transition to higher- $\mathrm{O}_{2}$ sedimentary redox conditions.

The Pacific Southern Ocean and the Equatorial Pacific below 3,500 $\mathrm{m}$ are two locations where there is ambiguity in LGM BWO reconstructions. Neither NBP9802-6PC nor several cores from depths between 2,744 and 4,849 m distributed throughout the Pacific Southern Ocean, both north and south of the APF, have glacial aU peaks, and all these cores have aU concentrations below 1 ppm (Chase et al., 2003). Concentrations of aU in TT018-PC72 and PC18 are low $(<0.5 \mathrm{ppm})$ and do not change on glacial-interglacial timescales (Jacobel et al., 2017, 2020). The TT013 cores in particular are susceptible to burndown of glacial aU, as they have linear accumulation rates below the $3 \mathrm{~cm} \mathrm{yr}^{-1}$ threshold previously suggested for aU preservation in the Equatorial Pacific (Jacobel et al., 2017). 

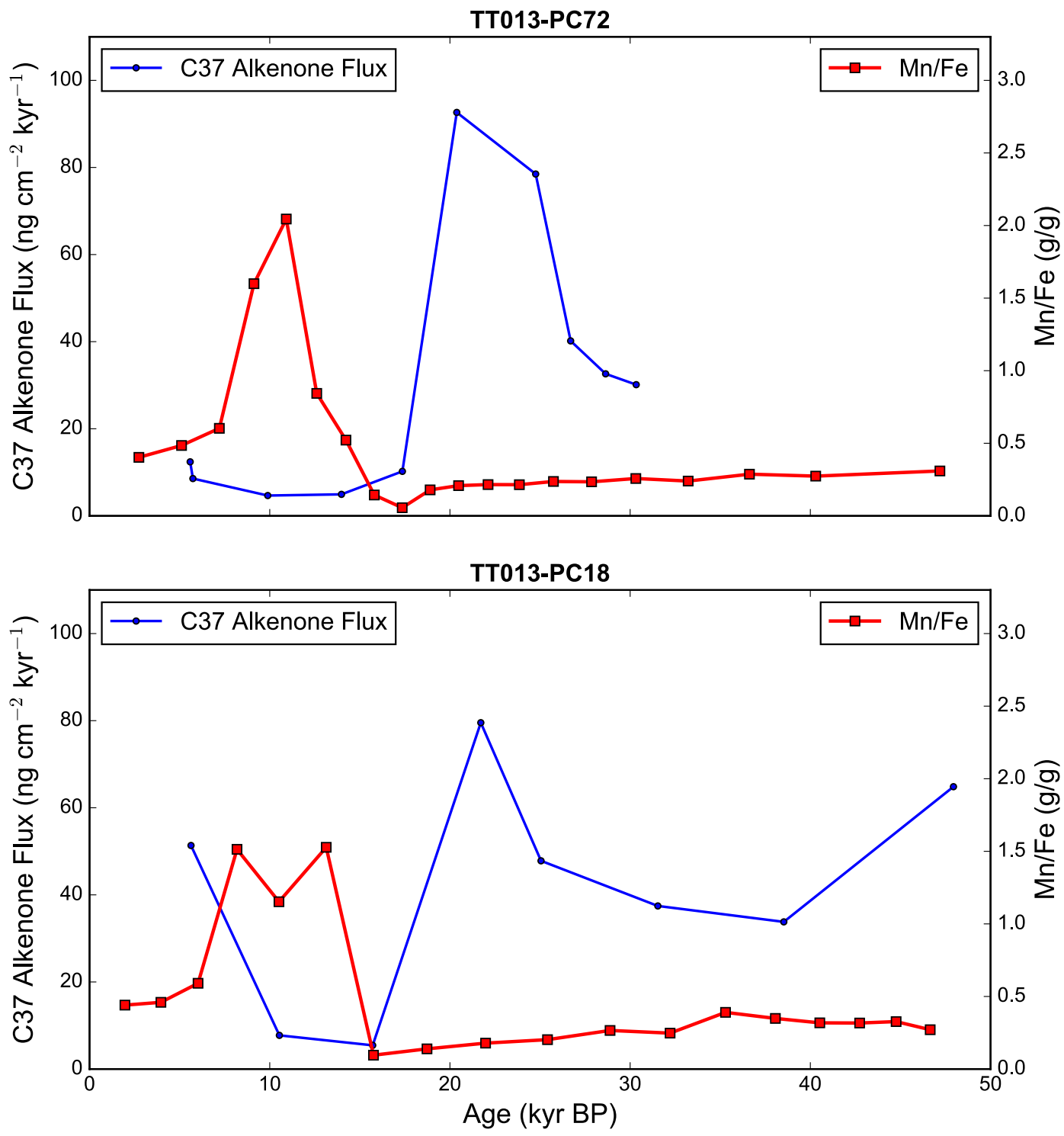

Figure 6. $\mathrm{Mn} / \mathrm{Fe}$ ratios (red, $\mathrm{g} / \mathrm{g}$ ) and $\mathrm{C} 37$ alkenone fluxes (blue, $\mathrm{ng} \mathrm{cm}^{-2} \mathrm{kyr}^{-1}$ ) from Equatorial Pacific cores TT013PC72 (top) and PC18 (bottom). Alkenone fluxes are from Anderson et al. (2019).

The lack of aU at depth in the Equatorial Pacific and Pacific Southern Ocean has permitted ambiguities in our understanding of the depth structure of respired $\mathrm{CO}_{2}$ storage in the deep Pacific during the LGM. In the modern ocean, AABW formed around the Antarctic continent flows northwards into the Pacific at depths below 4,000 m. As this AABW continues northward and is converted into southward-flowing, shallower Pacific Deepwater (found at depths of 2,000-4,000 m), its oxygen concentration decreases due to organic matter respiration. As a result, modern oxygen concentrations in the deep Pacific increase with depth below 2,000 m (e.g., Craig, 1971).

The presence of glacial aU peaks in the Equatorial Pacific only between 1,000 and 3,500 $\mathrm{m}$ has thus led to the suggestion that the LGM Pacific hosted a floating pool of respired $\mathrm{CO}_{2}$ and low- $\mathrm{O}_{2}$, with abyssal waters below 3,500 m hosting indistinguishably different BWO - a water mass geometry similar to today (Jacobel et al., 2017; Thiagarajan \& McManus, 2019). Combined with the lack of glacial aU in the Pacific Southern Ocean, this would seem to suggest that Antarctic waters filling the abyssal Pacific from the south were not significantly depleted in $\mathrm{O}_{2}$ during the LGM. 

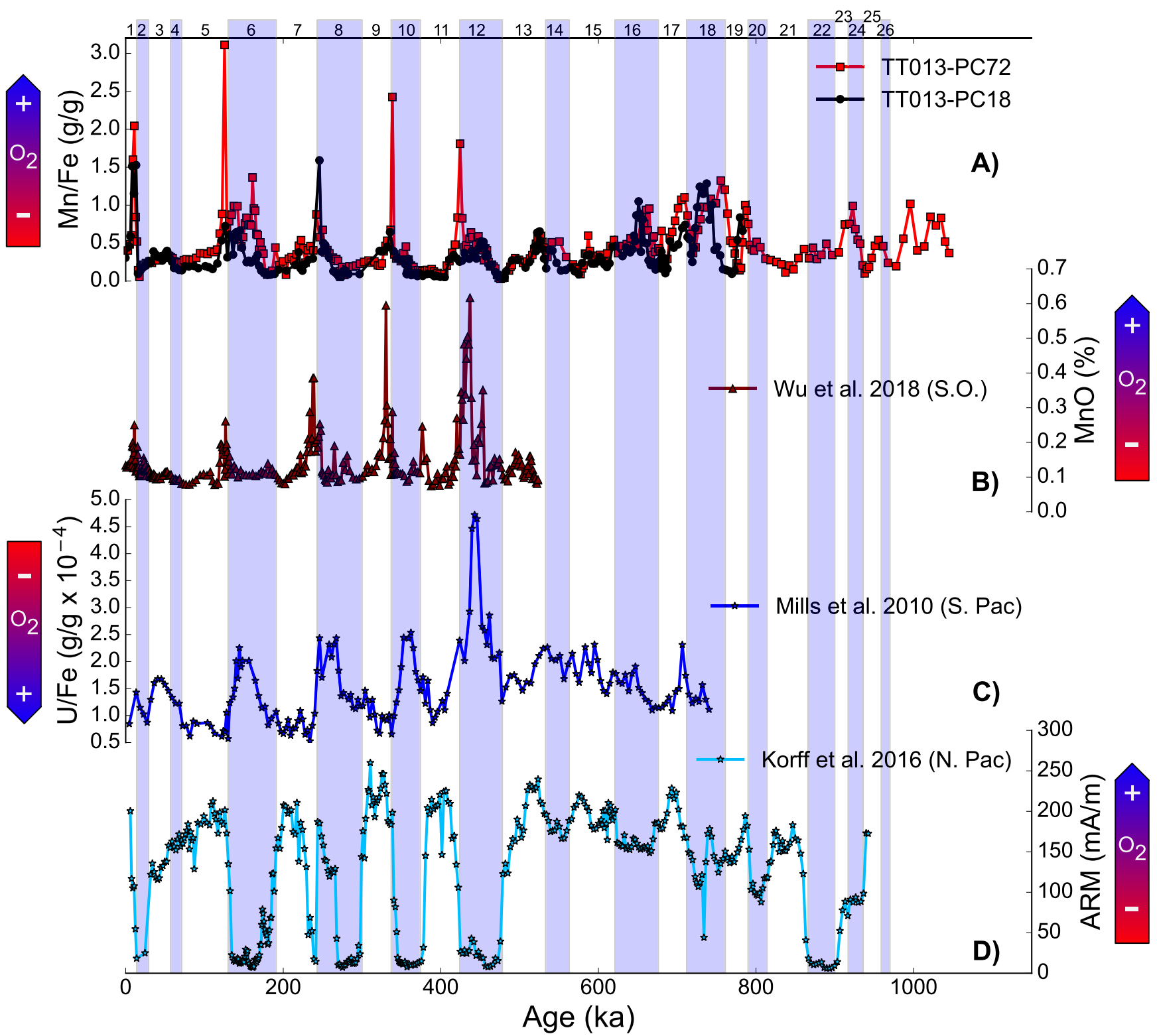

Figure 7. Records of bottom water oxygen from the Indo-Pacific over the past million years. Shaded blue intervals indicate glacial marine isotope stages (Lisiecki \& Raymo, 2005). Panel (a) shows Mn/Fe from TT013-PC72 (red) and -PC18 (black) in the Central Equatorial Pacific presented in this study. Panel (b) shows $\mathrm{MnO} \%$ from the Indian sector of the Southern Ocean from Wu et al. (2018). Panel (c) shows U/Fe ratios from metalliferous sediments in the Southeast Pacific from Mills et al. (2010). The low U/Fe ratios during interglacial periods are interpreted to reflect oxidative remobilization of uranium driven by increasing bottom water oxygen concentrations. Panel (d) shows anhysteretic remanent magnetization (ARM) from the Northwest Pacific Ocean presented by Korff et al. (2016). The low values during glacial periods reflect the dissolution of magnetite under reducing sedimentary porewater conditions driven by low bottom water oxygen concentrations. Arrows outside the label of each plot show the directional change in BWO indicated by each proxy.

However, our findings of BWO-driven deglacial Mn peaks in the Pacific Southern Ocean and $>3,500 \mathrm{~m}$ Equatorial Pacific instead suggest that waters in both the deep Southern Ocean and Pacific were enriched in respired $\mathrm{CO}_{2}$ and depleted in $\mathrm{O}_{2}$ during the LGM. Our results are consistent with the findings of Anderson et al. (2019), who attributed greater LGM biomarker preservation at TT013-PC72 and TT013-PC18 as being driven by lower BWO. Indeed, the correspondence in timing between decreased C37 alkenone fluxes and increased $\mathrm{Mn} / \mathrm{Fe}$ ratios in the TT013 cores is striking (Figure 6). As BWO concentrations increased during the deglaciation, authigenic Mn preservation became possible, while organic biomarkers were preserved less efficiently. The presence of alkenone peaks just below Mn peaks, as expected for oxygenation changes, in these cores where robust inorganic productivity proxies indicate no greater LGM export, further supports 
oxygen-driven preservation controlling alkenone abundances in the EEP, rather than changes in primary productivity, as has recently been argued by Raja and Rosell-Melé (2021).

\subsection{Spatial Extent of Mn Peaks During the Last Deglaciation}

In addition to the evidence for ventilation of the deep Equatorial Pacific and Southern Oceans during the last deglaciation from our data, we have compiled historical data where trace metal ( $\mathrm{Mn}$ and $\mathrm{Fe}$ ) abundances suggest low BWO during glacial periods, or increasing BWO during deglaciations (Figure 2). Deglacial authigenic Mn peaks are found in all three sectors of the Southern Ocean (Hillenbrand et al., 2021; Jaccard et al., 2016; Kumar, 1994; Wu et al., 2018), as well as the Central and Equatorial Pacific (Berger et al., 1983; Finney et al., 1988; Prahl et al., 1989). Recent studies have suggested that Pacific waters shallower than $1,000 \mathrm{~m}$ did not store more respired $\mathrm{CO}_{2}$ during the LGM (Chen et al., 2020; Hoogakker et al., 2018; Jacobel et al., 2020).

Our compiled historical deglacial Mn peaks all come from either the Equatorial Pacific, or the Southern Ocean south of the APF. Recent reconstructions using a variety of proxies $\left(\mathrm{Ba}_{\mathrm{xs}}\right.$ fluxes, opal fluxes, and ${ }^{231} \mathrm{~Pa} /{ }^{230} \mathrm{Th}$ ratios) from sites spanning both the eastern and central Equatorial Pacific have found increasing or unchanging export productivity during the deglaciation (Costa et al., 2017; Winckler et al., 2016). Faunal assemblages similarly suggest lower export productivity in the eastern Equatorial Pacific during the glacial periods compared to interglacial periods (Loubere et al., 2003). We thus contend that the deglacial Mn peaks previously discovered in the Equatorial Pacific (Berger et al., 1983; Finney et al., 1988; Prahl et al., 1989) reflect increasing BWO, just as the peaks we measured in TT013 cores. The peaks measured south of the APF all had proxies for export production measured in the same cores (Hillenbrand et al., 2021; Jaccard et al., 2016; Kumar, 1994; Kumar et al., 1995; Wu et al., 2018) that showed increasing or unchanging glacial to Holocene export productivity patterns. Thus, the Mn peaks in these cores can also be attributed to increasing deglacial BWO.

Our compilation of oxygenation-driven authigenic Mn peaks and other redox sensitive trace metals, as well as other recent studies employing different BWO proxies (e.g., Gottschalk et al., 2020) suggests that all sectors of the Southern Ocean, as well as the entirety of the Pacific below $1 \mathrm{~km}$, contained much greater respired $\mathrm{CO}_{2}$ and lower $\mathrm{O}_{2}$ during the $\mathrm{LGM}$, and that these waters were ventilated, releasing their respired $\mathrm{CO}_{2}$ during the last deglaciation. Given that roughly 55\% of the Pacific Ocean seafloor area is between 3 and $5 \mathrm{~km}$, and another $\sim 28 \%$ of the Pacific's seafloor area is below $5 \mathrm{~km}$ (Menard \& Smith, 1966), expanding the pool of waters rich in respired $\mathrm{CO}_{2}$ to these depths during the LGM suggests substantially greater glacial oceanic storage of respired $\mathrm{CO}_{2}$. This expansion would suggest a respired $\mathrm{CO}_{2}$ inventory on the order of $\sim 850$ Pg C (Anderson et al., 2019) rather than other estimates of 90-200 Pg C (Hoogakker et al., 2018).

Because relic authigenic Mn peaks are formed at an unknown depth beneath the sediment-water interface, and this depth will vary from core site to core site depending on the ambient sedimentary conditions, the precise timing of the Mn peaks cannot be compared from one core to another, nor between Mn peaks and other co-located proxies measured in the same core. Instead, in any given core, the age of the observed Mn peak represents an upper-limit for the initiation of changes in oxygenation. For example, in NBP1702, with a linear accumulation rate of $\sim 5 \mathrm{~cm} / \mathrm{kyr}$, an $\mathrm{Mn}$ peak that formed $5 \mathrm{~cm}$ below the sediment-water interface would have an apparent age 1 kyr older than the age of the oxygenation event that caused its downcore preservation.

The Mn peaks in TT013-PC72 and -PC18 have onsets at 15 kyr BP (Figure 6). In the NBP1702 and 9802 cores, the $\mathrm{Mn} / \mathrm{Fe}$ peaks have onsets at $\sim 19 \mathrm{kyr}$ BP. It is unlikely that these peaks truly formed 4 kyr apart. Authigenic Mn peak formation (i.e., the time of the deepening of the porewater redoxicline) closer to $15 \mathrm{kyr}$ $\mathrm{BP}$ is consistent with the timing of ocean $\mathrm{CO}_{2}$ release from the Southern Ocean recorded by boron isotopes in deep-sea corals (Rae et al., 2018) and in planktonic foraminifera (Martínez-Botí et al., 2015; Shao et al., 2019). However, Basak et al. (2018) observed destratification of the deep South Pacific based on neodymium isotopes that began at $18.8 \mathrm{kyr}$ BP. A major remaining question to be answered is whether ventilation took place synchronously throughout the Pacific Ocean, or whether it progressed slowly from south to north over thousands of years. Our records suggest that ventilation of the Southern Ocean started early during the deglacial period (Figure 4). However, records of the timing of deglacial deep North Pacific 
ventilation range from $\sim 15$ (Galbraith et al., 2007; Gorbarenko et al., 2020) to 18 ka (Du et al., 2018). The timescale of ventilation progression through the abyssal Pacific remains a major issue to be resolved in future studies.

\subsection{Onset of Respired $\mathrm{CO}_{2}$ Storage in the Deep Pacific After Marine Isotope Stage 12}

It is important to establish whether the respired $\mathrm{CO}_{2}$ storage and oxygen depletion in the deep Pacific during the LGM are ubiquitous features of all late-Pleistocene glacial periods. The trace metal records from TT013PC18 and -PC72 extend to 783 and 1045 ka, respectively. We compare our results with a 500 kyr record of authigenic Mn accumulation from the Indian sector of the Southern Ocean (Wu et al., 2018), a 700 kyr record of redox-sensitive trace metals from hydrothermal sediments in the Southeast Pacific (Mills et al., 2010), and a 950 kyr record of magnetite dissolution from the abyssal Northwest Pacific (Korff et al., 2016) (Figure 7). Mills et al. (2010) found uranium to iron (U/Fe) ratios that were high during glacial periods and low during interglacial periods, reflecting oxidative remobilization of solid-phase reduced uranium during high-BWO interglacial intervals. Korff et al. (2016) found low anhysteretic remanent magnetization in sediments from the North Pacific during glacial periods, reflecting the reductive dissolution of magnetic iron minerals induced by low BWO.

In addition to these records, diagenetic Mn enrichments were recently discovered in a large number of cores from 2,400 to 3,600 m depth from the West Antarctic margin, along the Bellingshausen Sea drift and western Antarctic Peninsula Rise (Hillenbrand et al., 2021).These Mn enrichments correspond to intervals of increasing export productivity, suggesting that they are driven by increasing deglacial BWO and are found at each of the past three terminations. Thus, the signature of increasing BWO during the deglaciation spans the entire latitudinal range of the deep Pacific and Southern Oceans.

The compiled records show a consistent pattern over the past $500 \mathrm{ka}$ (since MIS12) of low BWO during glacial periods from low ARM in the North Pacific, and ventilation during deglaciations from low U/Fe in the South Pacific, as well as increasing deglacial BWO from authigenic Mn peaks in the Indian Southern Ocean and Central Equatorial Pacific (Figure 7). Storage of respired $\mathrm{CO}_{2}$ in the deep Pacific has also been documented for the last three glacial periods based on authigenic U deposits (Jacobel et al., 2017). The variety of oxygen-sensitive proxies, and their distribution spanning the entire Indo-Pacific from 3,000 to 5,000 $\mathrm{m}$ depths, suggests that glacial-interglacial cycles since MIS12 have featured similar patterns of respired $\mathrm{CO}_{2}$ storage and oxygen depletion in the entirety of the deep Pacific Ocean.

However, none of the records have apparent signatures of glacial-interglacial BWO changes during glacial cycles preceding MIS12, between $1 \mathrm{Ma}$ and $500 \mathrm{ka}$. This interval is characterized by glacial periods with atmospheric temperature and $\mathrm{CO}_{2}$ (Lüthi et al., 2008) and ice volumes (Lisiecki \& Raymo, 2005) similar to glacial periods from $500 \mathrm{ka}$ to present, but "lukewarm" interglacial periods (MIS13, 15, 17, 19) with cooler temperatures, lower $\mathrm{CO}_{2}$, and greater ice volumes than the interglacial periods that followed (MIS 1, 5, 7, $9,11)$.

The lower atmospheric $\mathrm{CO}_{2}$ concentrations during the lukewarm interglacials has been attributed to a larger inventory of respired $\mathrm{CO}_{2}$ stored in the deep ocean compared to interglacials that followed (Jaccard et al., 2010, 2013). The mechanism for achieving greater respired $\mathrm{CO}_{2}$ storage in the deep ocean during lukewarm interglacials compared to recent ones is argued to be less efficient mixing in the Antarctic Zone of the Southern Ocean and poorer ventilation of the deep Southern Ocean (Barth et al., 2018; Howe \& Piotrowski, 2017; Jaccard et al., 2013). This mechanism would drive decreased glacial-interglacial variability in deep Pacific BWO (i.e., lower interglacial BWO) before MIS 12.

Our data are potentially consistent with weaker ventilation of the deep Southern Ocean during early lukewarm interglacials. We see no sharp authigenic Mn/Fe peaks during deglaciations preceding MIS 12 in TT013 cores, and Mills et al. (2010) found no glacial-interglacial variability in U/Fe during these intervals. If the deglacial increase in BWO was small, the porewater redoxicline may not deepen sufficiently to preserve a steady-state Mn peak or oxidatively remobilize an authigenic U peak. Quantitatively estimating the glacial-interglacial BWO change necessary to preserve authigenic Mn peaks in the Central Equatorial Pacific would require diagenetic modeling and is beyond the scope of this work. However, such modeling may be 
a fruitful avenue to pursue to place an upper limit on the glacial-interglacial BWO change allowable before MIS 12 that would not preserve authigenic Mn peaks.

\section{Conclusion}

We have documented the presence of authigenic manganese peaks throughout the Pacific and Southern Oceans that are uniquely attributable to increasing BWO concentrations during the last deglaciation. There is a growing body of evidence for reduced deep-water oxygen concentrations in the Pacific Ocean during the LGM, from a variety of different proxies. Our results provide complementary evidence for the deglacial ventilation and release of respired $\mathrm{CO}_{2}$ from these waters. We argue that the entirety of the Pacific below $1 \mathrm{~km}$ depth hosted lower BWO during the LGM, greatly expanding the volume of waters that stored respired carbon. Finally, we show that the storage and release of respired $\mathrm{CO}_{2}$ during glacial periods and deglaciations is a pervasive feature of the last five glacial cycles, but not during glacial cycles preceding MIS 12. While our results are qualitative and do not provide direct constraints on BWO concentrations, diagenetic modeling efforts may provide a path forward to more quantitatively interpret the ways glacial-interglacial changes in BWO concentrations affect downcore records of redox-sensitive trace metals.

\section{Data Availability Statement}

All data from this cruise have been submitted to be archived at the NOAA NCEI paleoclimatology data center. NBP1702 and NBP9802 data are available at https://www.ncdc.noaa.gov/paleo-search/study/31312. Data can be found at https://www.ncdc.noaa.gov/paleo-search/study/32373.

\section{Acknowledgments}

This work was performed with support from the National Science Foundation (NSF) over about 30 years. The TT013 and NBP9802 cores were collected during the U.S. JGOFS program. Their collection and analyses were supported by NSF OCE-9022301 and OPP95303398 to R. F. Anderson, and NSF OCE 9301097 to R. W. Murray. Coring and radiocarbon analyses on NBP1702 were funded by NSF OPP-1542962. XRF analysis on NBP9802 and NBP1702 cores, as well as additional radiocarbon measurements, was funded by an LDEO Climate Center Grant to F. J. Pavia. The LDEO core repository, especially Nichole Anest and Clara Chang, was instrumental in the processing and XRF scanning of the NBP9802 and 1702 cores. We thank the captains, crews, and science parties of the R. V. Thomas G. Thompson and R. V. Nathaniel B. Palmer, as well as Martin Q. Fleisher for support at sea in collecting the sediment cores. Discussions with Kassandra Costa, Allison Jacobel, and Theodore Present improved the quality of the manuscript, as did comments from two anonymous reviewers.

\section{References}

Ai, X. E., Studer, A. S., Sigman, D. M., Martínez-García, A., Fripiat, F., Thöle, L. M., et al. (2020). Southern Ocean upwelling, Earth's obliquity, and glacial-interglacial atmospheric $\mathrm{CO}_{2}$ change. Science, 370(6522), 1348-1352. https://doi.org/10.1126/science.abd2115

Allen, K. A., Sikes, E. L., Anderson, R. F., \& Rosenthal, Y. (2020). Rapid Loss of $\mathrm{CO}_{2}$ from the South Pacific Ocean during the last glacial termination. Paleoceanography and Paleoclimatology, 35(2), e2019PA003766. https://doi.org/10.1029/2019PA003766

Allen, K. A., Sikes, E. L., Honisch, B., Elmore, A. C., Guilderson, T. P., Rosenthal, Y., \& Anderson, R. F. (2015). Southwest Pacific deep water carbonate chemistry linked to high southern latitude climate and atmospheric $\mathrm{CO}_{2}$ during the last glacial termination. Quaternary Science Reviews, 122, 180-191. https://doi.org/10.1016/j.quascirev.2015.05.007

Anderson, R., Fleisher, M., \& Lao, Y. (2006). Glacial-interglacial variability in the delivery of dust to the central equatorial Pacific Ocean. Earth and Planetary Science Letters, 242(3-4), 406-414. https://doi.org/10.1016/j.epsl.2005.11.061

Anderson, R. F. (1982). Concentration, vertical flux, and remineralization of particulate uranium in seawater. Geochimica et Cosmochimica Acta, 46(7), 1293-1299. https://doi.org/10.1016/0016-7037(82)90013-8

Anderson, R. F., Ali, S., Bradtmiller, L. I., Nielsen, S. H. H., Fleisher, M. Q., Anderson, B. E., \& Burckle, L. H. (2009). Wind-driven upwelling in the Southern Ocean and the deglacial rise in atmospheric $\mathrm{CO}_{2}$. Science, 323(5920), 1443-1448. https://doi.org/10.1126/ science. 1167441

Anderson, R. F., Fleisher, M. Q., Lao, Y., \& Winckler, G. (2008). Modern $\mathrm{CaCO}_{3}$ preservation in equatorial Pacific sediments in the context of late-Pleistocene glacial cycles. Marine Chemistry, 111(1-2), 30-46. https://doi.org/10.1016/j.marchem.2007.11.011

Anderson, R. F., Sachs, J. P., Fleisher, M. Q., Allen, K. A., Yu, J., Koutavas, A., \& Jaccard, S. L. (2019). Deep-sea oxygen depletion and ocean carbon sequestration during the last Ice Age. Global Biogeochemical Cycles, 416(6876), 70-317. https://doi.org/10.1029/2018GB006049

Barnes, C. E., \& Cochran, J. K. (1990). Uranium removal in oceanic sediments and the oceanic U balance. Earth and Planetary Science Letters, 97(1-2), 94-101. https://doi.org/10.1016/0012-821X(90)90101-3

Barth, A. M., Clark, P. U., Bill, N. S., He, F., \& Pisias, N. G. (2018). Climate evolution across the Mid-Brunhes transition. Climate of the Past, 14(12), 2071-2087. https://doi.org/10.5194/cp-14-2071-2018

Basak, C., Fröllje, H., Lamy, F., Gersonde, R., Benz, V., Anderson, R. F., et al. (2018). Breakup of last glacial deep stratification in the South Pacific. Science, 359(6378), 900-904. https://doi.org/10.1126/science.aao2473

Berger, W. H., Finkel, R. C., Killingley, J. S., \& Marchig, V. (1983). Glacial-Holocene transition in deep-sea sediments: Manganese-spike in the east-equatorial Pacific. Nature, 303(5914), 231-233. https://doi.org/10.1038/303231a0

Boyle, E. A. (1990). Quaternary deepwater Paleoceanography. Science, 249(4971), 863-870. https://doi.org/10.1126/science.249.4971.863

Bradtmiller, L. I., Anderson, R. F., Sachs, J. P., \& Fleisher, M. Q. (2010). A deeper respired carbon pool in the glacial equatorial Pacific Ocean. Earth and Planetary Science Letters, 299(3-4), 417-425. https://doi.org/10.1016/j.epsl.2010.09.022

Broecker, W. S. (1982). Glacial to interglacial changes in ocean chemistry. Progress in Oceanography, 11(2), 151-197. https://doi. org/10.1016/0079-6611(82)90007-6

Bruland, K. W., Orians, K. J., \& Cowen, J. P. (1994). Reactive trace metals in the stratified central North Pacific. Geochimica et Cosmochimica Acta, 58(15), 3171-3182. https://doi.org/10.1016/0016-7037(94)90044-2

Burdige, D. J., \& Gieskes, J. M. (1983). A pore water/solid phase diagenetic model for manganese in marine sediments. American Journal of Science, 283(1), 29-47. https://doi.org/10.2475/ajs.283.1.29

Butzin, M., Heaton, T. J., Köhler, P., \& Lohmann, G. (2020). A short note on marine reservoir age simulations used in INTCAL20. Radiocarbon, 62, 1-871. https://doi.org/10.1017/RDC.2020.9

Calvert, S. E., \& Pedersen, T. F. (1996). Sedimentary geochemistry of manganese; implications for the environment of formation of manganiferous black shales. Economic Geology, 91(1), 36-47. https://doi.org/10.2113/gsecongeo.91.1.36 
Chase, Z., Anderson, R. F., Fleisher, M. Q., \& Kubik, P. W. (2003). Accumulation of biogenic and lithogenic material in the Pacific sector of the Southern Ocean during the past 40,000 years. Deep Sea Research Part II: Topical Studies in Oceanography, 50(3), 799-832. https:// doi.org/10.1016/s0967-0645(02)00595-7

Chen, T., Robinson, L. F., Burke, A., Claxton, L., Hain, M. P., Li, T., et al. (2020). Persistently well-ventilated intermediate-depth ocean through the last deglaciation. Nature Geoscience, 13(11), 733-738. https://doi.org/10.1038/s41561-020-0638-6

Colley, S., Thomson, J., \& Toole, J. (1989). Uranium relocations and derivation of quasi-isochrons for a turbidite/pelagic sequence in the Northeast Atlantic. Geochimica et Cosmochimica Acta, 53(6), 1223-1234. https://doi.org/10.1016/0016-7037(89)90058-6

Costa, K. M., Jacobel, A. W., McManus, J. F., Anderson, R. F., Winckler, G., \& Thiagarajan, N. (2017). Productivity patterns in the equatorial Pacific over the last 30,000 years. Global Biogeochemical Cycles, 31(5), 850-865. https://doi.org/10.1002/2016GB005579

Craig, H. (1971). The deep metabolism: Oxygen consumption in abyssal ocean water. Journal of Geophysical Research, 76(21), 5078-5086. https://doi.org/10.1029/JC076i021p05078

Du, J., Haley, B. A., Mix, A. C., Walczak, M. H., \& Praetorius, S. K. (2018). Flushing of the deep Pacific Ocean and the deglacial rise of atmospheric $\mathrm{CO}_{2}$ concentrations. Nature Geoscience, 11(10), 749-755. https://doi.org/10.1038/s41561-018-0205-6

Finney, B. P., Lyle, M. W., \& Heath, G. R. (1988). Sedimentation at MANOP Site H (eastern Equatorial Pacific) over the past 400,000 years: Climatically induced redox variations and their effects on transition metal cycling. Paleoceanography, 3(2), 169-189. https://doi. org/10.1029/PA003i002p00169

Froelich, P. N., Klinkhammer, G. P., Bender, M. L., Luedtke, N. A., Heath, G. R., Cullen, D., et al. (1979). Early oxidation of organic matter in pelagic sediments of the eastern Equatorial Atlantic: Suboxic diagenesis. Geochimica et Cosmochimica Acta, 43(7), 1075-1090. https:// doi.org/10.1016/0016-7037(79)90095-4

Galbraith, E. D., Jaccard, S. L., Pedersen, T. F., Sigman, D. M., Haug, G. H., Cook, M., et al. (2007). Carbon dioxide release from the North Pacific abyss during the last deglaciation. Nature, 449(7164), 890-893. https://doi.org/10.1038/nature06227

Gorbarenko, S. A., Shi, X., Liu, Y., Zou, J., Psheneva, O. Y., Bosin, A. A., et al. (2020). Evidence of Southern Ocean influence into the far Northwest Pacific (Northern Emperor Rise) since the Bølling-Allerød warming. Global and Planetary Change, 195, 103315. https://doi. org/10.1016/j.gloplacha.2020.103315

Gottschalk, J., Michel, E., Thöle, L. M., Studer, A. S., Hasenfratz, A. P., Schmid, N., et al. (2020). Glacial heterogeneity in Southern Ocean carbon storage abated by fast South Indian deglacial carbon release. Nature Communication, 11(1), 1-14. https://doi.org/10.1038/ s41467-020-20034-1

Gottschalk, J., Skinner, L. C., Lippold, J., Vogel, H., Frank, N., Jaccard, S. L., \& Waelbroeck, C. (2016). Biological and physical controls in the Southern Ocean on past millennial-scale atmospheric $\mathrm{CO}_{2}$ changes. Nature Communication, 7(1), 1-11. https://doi.org/10.1038/ ncomms 11539

Hayes, C. T., Anderson, R. F., Cheng, H., Conway, T. M., Edwards, R. L., Fleisher, M. Q., et al. (2018). Replacement times of a spectrum of elements in the North Atlantic based on Thorium supply. Global Biogeochemical Cycles, 32(9), 1294-1311. https://doi. org/10.1029/2017GB005839

Hillenbrand, C.-D., Crowhurst, S. J., Williams, M., Hodell, D. A., McCave, I. N., Ehrmann, W., et al. (2021). New insights from multi-proxy data from the West Antarctic continental rise: Implications for dating and interpreting Late Quaternary palaeoenvironmental records. Quaternary Science Reviews, 257, 106842. https://doi.org/10.1016/j.quascirev.2021.106842

Hoogakker, B. A. A., Elderfield, H., Schmiedl, G., McCave, I. N., \& Rickaby, R. E. M. (2015). Glacial-interglacial changes in bottom-water oxygen content on the Portuguese margin. Nature Geoscience, 8(1), 40-43. https://doi.org/10.1038/ngeo2317

Hoogakker, B. A. A., Lu, Z., Umling, N., Jones, L., Zhou, X., Rickaby, R. E. M., et al. (2018). Glacial expansion of oxygen-depleted seawater in the eastern tropical Pacific. Nature, 562(7727), 410-413. https://doi.org/10.1038/s41586-018-0589-X

Howe, J. N. W., \& Piotrowski, A. M. (2017). Atlantic deep water provenance decoupled from atmospheric $\mathrm{CO}_{2}$ concentration during the lukewarm interglacials. Nature Communication, 8(1), 2003. https://doi.org/10.1038/s41467-017-01939-w

Jaccard, S. L., Galbraith, E. D., Martínez-Garcia, A., \& Anderson, R. F. (2016). Covariation of deep Southern Ocean oxygenation and atmospheric $\mathrm{CO}_{2}$ through the last ice age. Nature, 530(7589), 207-210. https://doi.org/10.1038/nature16514

Jaccard, S. L., Galbraith, E. D., Sigman, D. M., \& Haug, G. H. (2010). A pervasive link between Antarctic ice core and subarctic Pacific sediment records over the past 800kyrs. Quaternary Science Reviews, 29(1-2), 206-212. https://doi.org/10.1016/j.quascirev.2009.10.007

Jaccard, S. L., Galbraith, E. D., Sigman, D. M., Haug, G. H., François, R., Pedersen, T. F., et al. (2009). Subarctic Pacific evidence for a glacial deepening of the oceanic respired carbon pool. Earth and Planetary Science Letters, 277(1-2), 156-165. https://doi.org/10.1016/j. epsl.2008.10.017

Jaccard, S. L., Hayes, C. T., Martínez-García, A., Hodell, D. A., Anderson, R. F., Sigman, D. M., \& Haug, G. H. (2013). Two modes of change in Southern Ocean productivity over the past million years. Science, 339(6126), 1419-1423. https://doi.org/10.1126/science.1227545

Jacobel, A. W., Anderson, R. F., Jaccard, S. L., McManus, J. F., Pavia, F. J., \& Winckler, G. (2020). Deep Pacific storage of respired carbon during the last ice age: Perspectives from bottom water oxygen reconstructions. Quaternary Science Reviews, 230, 106065. https://doi. org/10.1016/j.quascirev.2019.106065

Jacobel, A. W., McManus, J. F., Anderson, R. F., \& Winckler, G. (2017). Repeated storage of respired carbon in the equatorial Pacific Ocean over the last three glacial cycles. Nature Communication, 8(1), 1727. https://doi.org/10.1038/s41467-017-01938-x

Knox, F., \& McElroy, M. B. (1984). Changes in atmospheric $\mathrm{CO}_{2}$ : Influence of the marine biota at high latitude. Journal of Geophysical Research: Oceans, 89(D3), 4629-4637. https://doi.org/10.1029/JD089iD03p04629

Kohfeld, K. E., Le Quéré, C., Harrison, S. P., \& Anderson, R. F. (2005). Role of marine biology in glacial-interglacial $\mathrm{CO}_{2}$ cycles. Science, 308(5718), 74-78. https://doi.org/10.1126/science.1105375

Korff, L., von Dobeneck, T., Frederichs, T., Kasten, S., Kuhn, G., Gersonde, R., \& Diekmann, B. (2016). Cyclic magnetite dissolution in Pleistocene sediments of the abyssal northwest Pacific Ocean: Evidence for glacial oxygen depletion and carbon trapping. Paleoceanography, 31(5), 600-624. https://doi.org/10.1002/2015PA002882

Kumar, N. (1994). Trace metals and natural radionuclides as tracers of ocean productivity. New York.

Kumar, N., Anderson, R. F., Mortlock, R. A., Froelich, P. N., Kubik, P., Dittrich-Hannen, B., \& Suter, M. (1995). Increased biological productivity and export production in the glacial Southern Ocean. Nature, 378(6558), 675-680. https://doi.org/10.1038/378675a0

Lisiecki, L. E., \& Raymo, M. E. (2005). A Pliocene-Pleistocene stack of 57 globally distributed benthic $\delta^{18}$ O records. Paleoceanography, 20(1), PA1003. https://doi.org/10.1029/2004PA001071

Loubere, P., Fariduddin, M., \& Murray, R. W. (2003). Patterns of export production in the eastern Equatorial Pacific over the past 130,000 years. Paleoceanography, 18(2), 1028. https://doi.org/10.1029/2001PA000658 
Lu, W., Rickaby, R. E. M., Hoogakker, B. A. A., Rathburn, A. E., Burkett, A. M., Dickson, A. J., et al. (2020). I/Ca in epifaunal benthic foraminifera: A semi-quantitative proxy for bottom water oxygen in a multi-proxy compilation for glacial ocean deoxygenation. Earth and Planetary Science Letters, 533, 116055. https://doi.org/10.1016/j.epsl.2019.116055

Lüthi, D., Le Floch, M., Bereiter, B., Blunier, T., Barnola, J.-M., Siegenthaler, U., et al. (2008). High-resolution carbon dioxide concentration record 650,000-800,000 years before present. Nature, 453(7193), 379-382. https://doi.org/10.1038/nature06949

Mangini, A., Eisenhauer, A., \& Walter, P. (1990). Response of manganese in the ocean to the climatic cycles in the Quaternary. Paleoceanography, 5(5), 811-821. https://doi.org/10.1029/PA005i005p00811

Mangini, A., Eisenhauer, A., \& Walter, P. (1991). A spike of $\mathrm{CO}_{2}$ in the atmosphere at glacial-interglacial boundaries induced by rapid deposition of manganese in the oceans. Tellus B: Chemical and Physical Meteorology, 43(2), 97-105. https://doi.org/10.1034/j.1600-0889.1991. t01-1-00004.x

Mangini, A., Jung, M., \& Laukenmann, S. (2001). What do we learn from peaks of uranium and of manganese in deep sea sediments? Marine Geology, 177(1-2), 63-78. https://doi.org/10.1016/S0025-3227(01)00124-4

Mangini, A., Rutsch, H.-J., Frank, M., Eisenhauer, A., \& Eckhardt, J. D. (1994). Is there a relationship between atmospheric $\mathrm{CO}_{2}$ and manganese in the ocean? In Carbon cycling in the Glacial Ocean: Constraints on the Ocean's role in global change (Vol. 46, pp. 87-104). Berlin, Heidelberg: Springer. https://doi.org/10.1007/978-3-642-78737-9_5

Martínez-Botí, M. A., Marino, G., Foster, G. L., Ziveri, P., Henehan, M. J., Rae, J. W. B., et al. (2015). Boron isotope evidence for oceanic carbon dioxide leakage during the last deglaciation. Nature, 518(7538), 219-222. https://doi.org/10.1038/nature14155

Martínez-Garcia, A., Sigman, D. M., Ren, H., Anderson, R. F., Straub, M., Hodell, D. A., et al. (2014). Iron fertilization of the Subantarctic Ocean during the Last Ice Age. Science, 343(6177), 1347-1350. https://doi.org/10.1126/science.1246848

McManus, J., Berelson, W. M., Klinkhammer, G. P., Hammond, D. E., \& Holm, C. (2005). Authigenic uranium: Relationship to oxygen penetration depth and organic carbon rain. Geochimica et Cosmochimica Acta, 69(1), 95-108. https://doi.org/10.1016/j.gca.2004.06.023

Menard, H. W., \& Smith, S. M. (1966). Hypsometry of ocean basin provinces. Journal of Geophysical Research, 71(18), 4305-4325. https:// doi.org/10.1029/JZ071i018p04305

Mills, R. A., Taylor, S. L., Pälike, H., \& Thomson, J. (2010). Hydrothermal sediments record changes in deep water oxygen content in the SE Pacific. Paleoceanography, 25(4), PA4226. https://doi.org/10.1029/2010PA001959

Murray, R. W., Knowlton, C., Leinen, M., Mix, A. C., \& Polsky, C. H. (2000). Export production and carbonate dissolution in the central equatorial Pacific Ocean over the past 1 Myr. Paleoceanography, 15(6), 570-592. https://doi.org/10.1029/1999PA000457

Murray, R. W., Leinen, M., Murray, D. W., Mix, A. C., \& Knowlton, C. W. (1995). Terrigenous Fe input and biogenic sedimentation in the glacial and interglacial equatorial Pacific Ocean. Global Biogeochemical Cycles, 9(4), 667-684. https://doi.org/10.1029/95GB02833

Petit, J. R., Jouzel, J., Raynaud, D., Barkov, N. I., Barnola, J. M., Basile, I., et al. (1999). Climate and atmospheric history of the past 420,000 years from the Vostok ice core, Antarctica. Nature, 399, 429-436. https://doi.org/10.1038/20859

Prahl, F. G., Muehlhausen, L. A., \& Lyle, M. (1989). An organic geochemical assessment of oceanographic conditions at Manop Site C over the past 26,000 years. Paleoceanography, 4(5), 495-510. https://doi.org/10.1029/PA004i005p00495

Rae, J. W. B., Burke, A., Robinson, L. F., Adkins, J. F., Chen, T., Cole, C., et al. (2018). $\mathrm{CO}_{2}$ storage and release in the deep Southern Ocean on millennial to centennial timescales. Nature, 562(7728), 569-573. https://doi.org/10.1038/s41586-018-0614-0

Raja, M., \& Rosell-Melé, A. (2021). Appraisal of sedimentary alkenones for the quantitative reconstruction of phytoplankton biomass. Proceedings of the National Academy of Sciences, 118(2), e2014787118. https://doi.org/10.1073/pnas.2014787118

Ren, H., Studer, A. S., Serno, S., Sigman, D. M., Winckler, G., Anderson, R. F., et al. (2015). Glacial-to-interglacial changes in nitrate supply and consumption in the subarctic North Pacific from microfossil-bound $\mathrm{N}$ isotopes at two trophic levels. Paleoceanography, 30(9), 1217-1232. https://doi.org/10.1002/2014PA002765

Ronge, T. A., Tiedemann, R., Lamy, F., Köhler, P., Alloway, B. V., De Pol-Holz, R., et al. (2016). Radiocarbon constraints on the extent and evolution of the South Pacific glacial carbon pool. Nature Communication, 7, 11487. https://doi.org/10.1038/ncomms11487

Shao, J., Stott, L. D., Gray, W. R., Greenop, R., Pecher, I., Neil, H. L., et al. (2019). Atmosphere-ocean $\mathrm{CO}_{2}$ exchange across the last deglaciation from the boron isotope proxy. Paleoceanography and Paleoclimatology, 34(10), 1650-1670. https://doi.org/10.1029/2018PA003498

Shaw, T. J., Sholkovitz, E. R., \& Klinkhammer, G. (1994). Redox dynamics in the Chesapeake Bay: The effect on sediment/water uranium exchange. Geochimica et Cosmochimica Acta, 58(14), 2985-2995. https://doi.org/10.1016/0016-7037(94)90173-2

Sigman, D. M., Altabet, M. A., McCorkle, D. C., François, R., \& Fischer, G. (1999). The $\delta^{15} \mathrm{~N}$ of nitrate in the southern ocean: Consumption of nitrate in surface waters. Global Biogeochemical Cycles, 13(4), 1149-1166. https://doi.org/10.1029/1999GB900038

Sigman, D. M., Hain, M. P., \& Haug, G. H. (2010). The polar ocean and glacial cycles in atmospheric $\mathrm{CO}_{2}$ concentration. Nature, 466(7302), 47-55. https://doi.org/10.1038/nature09149

Studer, A. S., Sigman, D. M., Martínez-García, A., Benz, V., Winckler, G., Kuhn, G., et al. (2015). Antarctic zone nutrient conditions during the last two glacial cycles. Paleoceanography, 30(7), 845-862. https://doi.org/10.1002/2014PA002745

Thiagarajan, N., \& McManus, J. F. (2019). Productivity and sediment focusing in the eastern Equatorial Pacific during the last 30,000 years. Deep Sea Research Part I: Oceanographic Research Papers, 147, 100-110. https://doi.org/10.1016/j.dsr.2019.03.007

Umling, N. E., \& Thunell, R. C. (2018). Mid-depth respired carbon storage and oxygenation of the eastern Equatorial Pacific over the last 25,000 years. Quaternary Science Reviews, 189, 43-56. https://doi.org/10.1016/j.quascirev.2018.04.002

Volk, T., \& Hoffert, M. I. (1985). Ocean carbon pumps: Analysis of relative strengths and efficiencies in ocean-driven atmospheric $\mathrm{CO}_{2}$

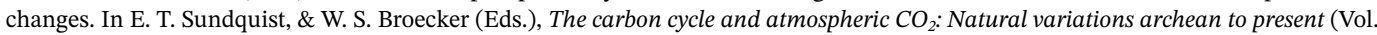
35B, pp. 99-110). Washington, DC: American Geophysical Union.

Wang, X. T., Sigman, D. M., Prokopenko, M. G., Adkins, J. F., Robinson, L. F., Hines, S. K., et al. (2017). Deep-sea coral evidence for lower Southern Ocean surface nitrate concentrations during the last ice age. Proceedings of the National Academy of Sciences, 114(13), 3352-3357. https://doi.org/10.1073/pnas.1615718114

Winckler, G., Anderson, R. F., Jaccard, S. L., \& Marcantonio, F. (2016). Ocean dynamics, not dust, have controlled equatorial Pacific productivity over the past 500,000 years. Proceedings of the National Academy of Sciences, 113(22), 6119-6124. https://doi.org/10.1073/ pnas. 1600616113

Wu, L., Wang, R., Xiao, W., Krijgsman, W., Li, Q., Ge, S., \& Ma, T. (2018). Late quaternary deep stratification-climate coupling in the Southern Ocean: Implications for changes in Abyssal carbon storage. Geochemistry Geophysics Geosystems, 19(2), 379-395. https://doi. org/10.1002/2017GC007250

Yang, Y. L., Elderfield, H., Pedersen, T. F., \& Ivanovich, M. (1995). Geochemical record of the Panama basin during the last glacial maximum carbon event shows that the glacial ocean was not suboxic. Geology, 23(12), 1115-1118. https://doi.org/10.1130/0091-7613(1995) $023<1115$ :grotpb $>2.3 . c 0 ; 2$ 